\title{
Oxidized low-density lipoprotein and $\beta$-glycerophosphate synergistically induce endothelial progenitor cell ossification
}

\author{
Li LIU ${ }^{1}$, Zhi-zhong LIU ${ }^{1}$, Hui CHEN ${ }^{2}$, Guo-jun ZHANG ${ }^{1}$, Yu-hua KONG ${ }^{1}$, Xi-xiong KANG ${ }^{1, *}$ \\ ${ }^{1}$ Center for Laboratory Diagnosis, Beijing Tiantan Hospital Affiliated to Capital Medical University, Beijing 100050, China; ${ }^{2}$ Department \\ of Clinical Laboratory, Beijing Boai Hospital, Beijing 100077, China
}

\begin{abstract}
Aim: To investigate the ability of ox-LDL to induce ossification of endothelial progenitor cells (EPCs) in vitro and explored whether oxidative stress, especially hypoxia inducible factor-1 $\alpha$ (HIF-1 $\alpha$ ) and reactive oxygen species (ROS), participate in the ossific process. Methods: Rat bone marrow-derived endothelial progenitor cells (BMEPCs) were cultured in endothelial growth medium supplemented with VEGF $(40 \mathrm{ng} / \mathrm{mL})$ and bFGF $(10 \mathrm{ng} / \mathrm{mL})$. The cells were treated with oxidized low-density lipoprotein (ox-LDL, $5 \mu \mathrm{g} / \mathrm{mL})$ and/or $\beta$-glycerophosphate ( $\beta$-GP, $10 \mathrm{mmol} / \mathrm{L})$. Calcium content and Von Kossa staining were used as the measures of calcium deposition. Ossific gene expression was determined using RT-PCR. The expression of osteocalcin (OCN) was detected with immunofluorescence. Alkaline phosphatase (ALP) activity was analyzed using colorimetric assay. Intercellular reactive oxygen species (ROS) were measured with flow cytometry.

Results: BMEPCs exhibited a spindle-like shape. The percentage of cells that expressed the cell markers of EPCs CD34, CD133, and kinase insert domain-containing receptor (KDR) were $46.2 \% \pm 5.8 \%, 23.5 \% \pm 4.0 \%$, and $74.3 \% \pm 8.8 \%$, respectively. Among the total cells, $78.3 \% \pm 4.2 \%$ were stained with endothelial-specific fluorescence. Treatment of BMEPCs with ox-LDL significantly promoted calcium deposition, which was further significantly enhanced by co-treatment with $\beta$-GP. The same treatments significantly increased the gene expression of core-binding factor a-1 (cbfa-1) and OCN, while decreased the gene expression of osteoprotegerin (OPG). The treatments also significantly enhanced the activity of ALP, but did not affect the number of $\mathrm{OCN}^{+}$cells. Furthermore, the treatments significantly increased ROS and activated the hypoxia inducible factor-1 $\alpha$ (HIF-1 $\alpha$ ). In all these effects, ox-LDL acted synergistically with $\beta$-GP.

Conclusion: Ox-LDL and $\beta$-GP synergistically induce ossification of BMEPCs, in which an oxidizing mechanism is involved.
\end{abstract}

Keywords: atherosclerosis; vascular calcification; oxidized low-density lipoprotein; $\beta$-glycerophosphate; endothelial progenitor cells; ossification; oxidized stress

Acta Pharmacologica Sinica (2011) 32: 1491-1497; doi: 10.1038/aps.2011.128; published online 31 Oct 2011

\section{Introduction}

Calcification that occurs in nonosseous tissue is called ectopic calcification. Calcification in vessel walls is primarily thought of as a process of degeneration that follows atherosclerosis. Matrix vesicles containing phosphorites and some boneassociated genes and proteins are found in atherosclerotic areas, which indicates that vascular calcification is a proactiveregulated phenomenon similar to bone formation ${ }^{[1]}$. Oxidative stress and inflammation are considered the main stimuli of vascular calcification, but the mechanism remains unclear ${ }^{[2]}$.

Smooth muscle cells have been used as an effective model

\footnotetext{
* To whom correspondence should be addressed.

E-mail kangxx@vip.sina.com

Received 2011-05-04 Accepted 2011-08-22
}

for studying vascular calcification in vitro ${ }^{[3]}$. However, there are other kinds of cells that also contribute to vascular pathology. Stem cells from bone marrow, such as marrow stromal cells (MSCs), endothelial progenitor cells (EPCs) and hematopoietic stem cells (HSCs), have many similar functions and potentials of transdifferentiation. Recent research has shown that EPCs participate in vascular pathology through a diphasic action. On one hand, EPCs homing into lesions and contribute to neovascularization and re-endothelialization after vessel injury. On the other hand, because of their stem cell characteristics, EPCs express phenotypes of fibration or ossification rather than differentiating into functional cells in certain abnormal microenvironments, which could aggravate vascular injury. It has been reported that EPCs express osteocalcin (OCN) in patients with coronary atherosclerosis or 
severe aortic valve stenosis ${ }^{[4,5]}$. Furthermore, EPCs were found in the areas of calcium deposition ${ }^{[6]}$. Local calcium deposition and microcalcification in the vessel wall could play a role in the adherence of circulating EPC populations and perhaps their differentiation towards an osteogenic phenotype. The phenotypes expressed by EPCs are determined by the local microenvironment. All of these studies implied a close correlation between endothelial differentiation and calcification. Unfortunately, research has focused only on transdifferentiation of EPCs in vivo. Whether EPCs can be induced to ossify in vitro and what factors might contribute to the transdifferentiation remains unknown.

Oxidized low-density lipoprotein (ox-LDL) has a dramatic effect on atherosclerosis ${ }^{[7]}$. Ox-LDL stimuli can cause endothelial cells to lose their vaso-protective effect and damage EPCs by triggering apoptosis, accelerating senescence and inhibiting endothelialization $^{[8-10]}$. Ox-LDL also induces vascular smooth muscle cells to express genes associated with bone formation by up-regulating osterix ${ }^{[11]}$, which is considered a risk factor for calcification.

In this study, we examined in detail the ability of ox-LDL to induce ossification of EPCs in vitro and explored whether oxidative stress, especially hypoxia inducible factor-1a (HIF-1a) and reactive oxygen species (ROS), participate in the ossific process. The results may provide a new understanding of the role of stem cells in vascular calcification.

\section{Materials and methods Reagents}

The materials used in the experiments were from the following sources: Endothelial growth medium was purchased from Cambrex Corporation (Charles, IA, USA). VEGF and bFGF were purchased from PeproTech Asia (Rehovot, Israel). Fluorescein isothiocyanate-labeled lectin from ulex europaeus agglutinin (FITC-UEA-1), 2' $7^{\prime}$-dichlorofluorescin diacetate (DCHF-DA), $\beta$-glycerophosphate ( $\beta$-GP) and fibronectin were all obtained from Sigma-Aldrich (USA). The Reverse Transcription System kit and the GoTaq qPCR Master Mix kit were obtained from Promega (Madison, WI, USA). The Sensolyte pNPP Alkaline Phosphatase ELISA Assay kit was purchased from AnaSpec Company (Fremont, CA, USA). The primary antibodies CD34-PerCP Cy5.5 and KDR-Alexa Fluor 647 were obtained from Becton Dickinson (San Jose, CA, USA). CD133PE antibody was from eBioscience (San Diego, CA, USA). 1,1'-dioctadecyl-3,3,3', 3'-tetramethyl-indocarbocyaninelabeled acetylated low-density lipoprotein (DiI-ac-LDL) and ox-LDL (MDA=50 nmol/mL) were purchased from XieSheng Biotechnology Limited-liability Company (Beijing, China). Sprague-Dawley rats (SPF/VAF) were purchased from Vital River Laboratories (Beijing, China); the certificate number was SCXX2006-0009.

\section{Ethics}

Animal experiments were approved by the Institutional Ethics Committee of Beijing Tiantan Hospital, China. The experiments were performed according to the National Research
Council's guidelines.

\section{Cell culture}

Bone marrow-derived endothelial progenitor cells (BMEPCs) were cultured as previously described ${ }^{[12]}$. In brief, bone marrow was aspirated from tibias and femurs of Sprague-Dawley rats (100 g in weight) and washed with Dulbecco's modified Eagle medium (DMEM) containing 5\% fetal bull serum. Bone marrow-derived mononuclear cells (BMMNCs) were isolated with Ficoll-Paque (GE Healthcare, Sweden) density-gradient centrifugation. After being washed twice with PBS, BMMNCs $\left(1 \times 10^{6} / \mathrm{mL}\right)$ were plated into six-well plates coated with fibronectin and cultured with endothelial growth medium (EGM) supplemented with $40 \mathrm{ng} / \mathrm{mL}$ VEGF and $10 \mathrm{ng} / \mathrm{mL}$ bFGF. Culture medium was renewed every three days.

\section{Identification of EPCs}

To identify their characteristics, the attached cells were trypsinized and labeled directly with three fluorescent antibodies: CD34-PerCP Cy5.5, CD133-PE, and KDR-Alexa Fluor 647. Cell fluorescence was measured by the FACSCalibur flow cytometer (Becton Dickinson). Cellquest software was used to analyze the ratios of positive cells. Additional cells were incubated with $2.4 \mu \mathrm{g} / \mathrm{mL}$ DiI-ac-LDL for $1 \mathrm{~h}$ at $37^{\circ} \mathrm{C}$, fixed in $2 \%$ paraformaldehyde and stained with $10 \mu \mathrm{g} / \mathrm{mL}$ FITC-UEA-1 for $40 \mathrm{~min}$. The nuclei were stained with Hoechst 33342. Fluorescence microscopy (Olympus, DP71) was used to identify the percentage of dual-positive cells.

\section{Treatment with ox-LDL}

The results of preliminary experiments showed that $5 \mu \mathrm{g} / \mathrm{mL}$ ox-LDL had no significant impact on cell survival after $14 \mathrm{~d}$ of incubation. This concentration could be used for ossific induction. After attachment, the primary passages were exposed to $5 \mu \mathrm{g} / \mathrm{mL}$ ox-LDL, $10 \mathrm{mmol} / \mathrm{L} \beta$-GP, or $5 \mu \mathrm{g} / \mathrm{mL}$ ox-LDL plus $10 \mathrm{mmol} / \mathrm{L} \beta$-GP. Historically, $\beta$-GP has been thought to act solely as a phosphate donor and as such was required for the mineralization of primary cell cultures in vitro ${ }^{[11]}$. Cells were maintained in normal growth medium as a control. Osteogenic differentiation was evaluated as explained below.

\section{Calcium staining and quantification}

Mineralization in induced cells were investigated using Von Kossa staining as previously described ${ }^{[13]}$. Briefly, fixed cells were incubated in 5\% silver nitrate solution for $30 \mathrm{~min}$ in the dark. The cells were then washed with distilled water and exposed to light for $45 \mathrm{~min}$. Calcium particles were observed in visual fields at a magnification of $\times 40$.

The treated cells were washed twice with PBS and rinsed in $0.6 \mathrm{~mol} / \mathrm{L} \mathrm{HCl}$. Intracellular calcium was extracted after incubating the cells for $24 \mathrm{~h}$ at $37^{\circ} \mathrm{C}$ with continuous shaking. The supernatant was collected by centrifugation $(1000 \times g$ for $5 \mathrm{~min}$ ). Calcium concentration was determined by the autobiochemistry analyzer (Roche P800, Switzerland). The calcium content was normalized to total protein content as determined by the Bradford method. 


\section{Expression of osteogenic genes}

Total RNA isolation and reverse transcription polymerase chain reaction (RT-PCR) were performed. Briefly, the cells of interest were lysed with TRIzol reagent (Invitrogen, CA, USA). The target genes were amplified using the Reverse Transcription System kit and the GoTaq qPCR Master Mix kit. The genes of interest included the following: core-binding factor a-1 (cbfa-1), which serves as the transcription factor triggering the expression of major osteoblast-specific lineage genes; osteoprotegerin (OPG), which acts as a suppressive signal of vascular calcification in normal cells; and OCN, which is the classic and mature marker for bone formation. The primers (Invitrogen, Shanghai, China) are shown in Table 1. The ratios of associated genes to beta-actin were analyzed semiquantitatively with Quantity One software (Bio-Rad, USA).

\section{ALP activity}

Alkaline phosphatase (ALP) activity of the induced cells was quantified using the Sensolyte pNPP Alkaline Phosphatase ELISA Assay Kit according to the manufacturer's instructions. The yellow product, p-nitrophenol, was measured by the microplate reader (Thermo, MK3) at a wavelength of 405 $\mathrm{nm}$. ALP activity was standardized according to total protein content.

\section{Immunofluorescence for osteocalcin}

Immunofluorescent staining was used to detect osteocalcin. BMEPCs were fixed in $4 \%$ paraformaldehyde for $20 \mathrm{~min}$ and blocked with anti-serum containing $0.5 \%$ Triton for $40 \mathrm{~min}$ at room temperature. The cells were then incubated with a primary monoclonal antibody targeted to osteocalcin (Santa Cruz, CA, USA) at $4{ }^{\circ} \mathrm{C}$ overnight. The cell were incubated with a secondary antibody, labeled with FITC (Jackson ImmunoResearch, PA, USA), at $37^{\circ} \mathrm{C}$ for $40 \mathrm{~min}$. Hoechst 33342 was used to stain cell nuclei. Cells were washed with PBS between each step.

\section{Oxidative stress}

Intracellular ROS was detected to evaluate oxidative status. Cells were loaded with $10 \mu \mathrm{mol} / \mathrm{L}$ DCHF-DA at $37^{\circ} \mathrm{C}$ for
$1 \mathrm{~h}$, washed with PBS and harvested gently. DCHF-DA is a stable fluorescent ROS-sensitive compound, which is oxidized by hydrogen peroxide or low-molecular-weight peroxides to produce the green fluorescence of 2 ', 7 '-dihydrogendichlorofluorescein (DCF). DCF in cells was measured using flow cytometry. Fluorescence intensity represented the level of ROS. The mean fluorescence for each sample was analyzed by Cellquest software.

\section{Statistical analysis}

All data were presented as the mean \pm standard deviation (SD). The differences between groups were analyzed by Student's $t$ test. A value of $P<0.05$ was considered statistically significant.

\section{Results}

\section{Characteristics of EPCs derived from bone marrow}

BMMNCs were cultured in endothelial growth medium for $7 \mathrm{~d}$ and exhibited the typical spindle-like shapes of endothelial progenitor cells (Figure 1A). Endothelial characteristics were assessed by the uptake of DiI-ac-LDL and the binding of FITC-UEA-1. Approximately $78.3 \% \pm 4.2 \%$ of total adherent cells were dual-positive (Figure 1B-1D), indicating that they expressed the scavenger receptor for ac-LDL and the ligand for UEA-1. Furthermore, the cell markers of EPCs were displayed. (Figure 1E-1G). The percentages of CD34, CD133, and KDR were $46.2 \% \pm 5.8 \%, 23.5 \% \pm 4.0 \%$, and $74.3 \% \pm 8.8 \%$, respectively. On the basis of these characteristics, the cells could be considered as BMEPCs ${ }^{[12]}$.

\section{Increased calcium deposition in BMEPCs}

Calcium deposition is an early event of ossification. BMEPCs were cultured in $5 \mu \mathrm{g} / \mathrm{mL}$ ox-LDL in the absence or presence of $\beta$-GP for $14 \mathrm{~d}$. The concentration of intracellular calcium in control cells was $4.4 \pm 0.95 \mu \mathrm{g} / \mathrm{mg}$ protein. Both ox-LDL and $\beta$-GP significantly increased intracellular calcium deposition. The values were $12.3 \pm 3.2 \mu \mathrm{g} / \mathrm{mg}$ protein $(P<0.05)$ and $17.2 \pm 2.0 \mu \mathrm{g} / \mathrm{mg}$ protein $(P<0.01)$, respectively. When ox-LDL and $\beta$-GP were combined, calcium deposition increased 6.1fold $(28.0 \pm 2.4 \mu \mathrm{g} / \mathrm{mg}$ protein, $P<0.01)$ compared with the control and 2.3-fold compared with ox-LDL alone $(P<0.01)$. The

Table 1. Primers for target genes.

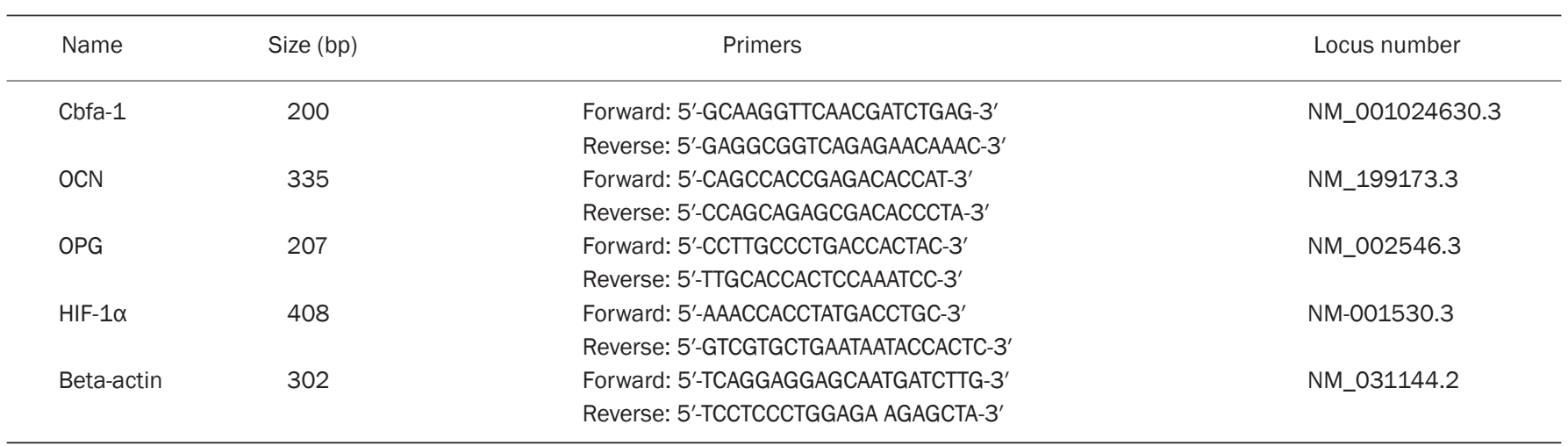



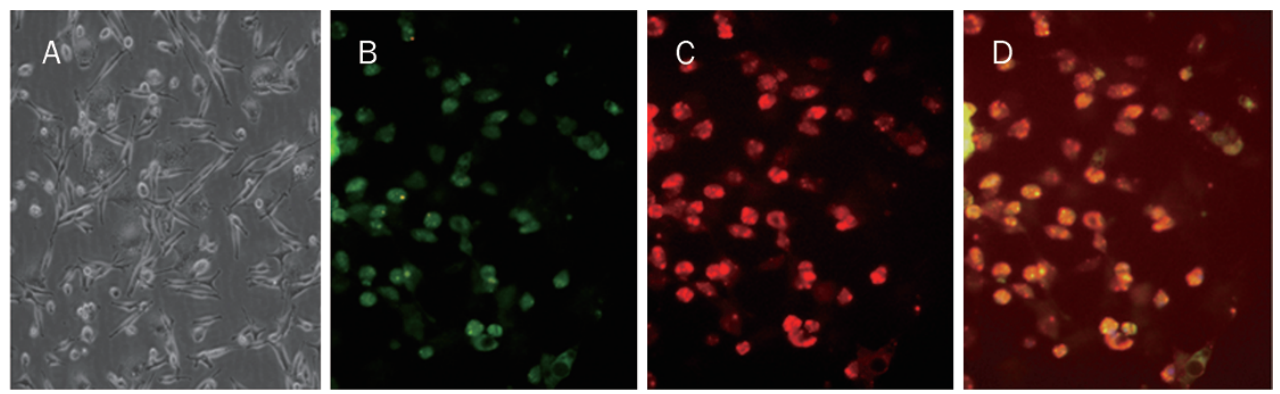

Figure 1. Characterization of EPCs. Mononuclear cells from bone marrow were cultured in endothelial growth medium for $7 \mathrm{~d}$. (A) BMEPCs displayed spindle-like shapes under bright field
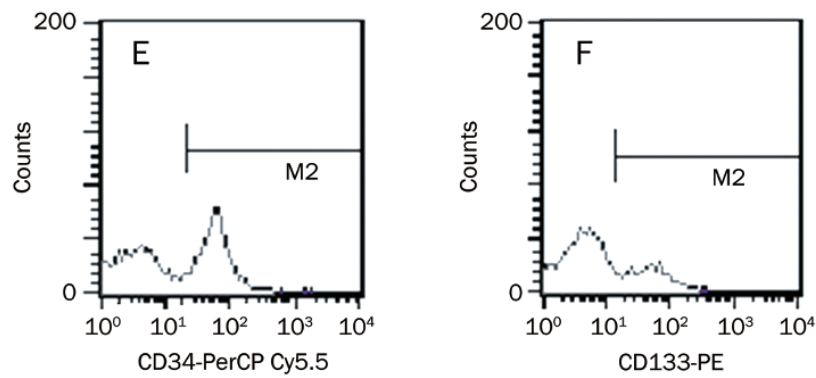

results were consistent with the Von Kossa staining (Figure 2). Ox-LDL not only increased intracellular calcium when used alone but also enhanced the effect of $\beta-G P$.

\section{Changes in bone-associated genes in BMEPCs}

For the gene expression analyses, BMEPCs were cultured for $7 \mathrm{~d}$ in the presence of ox-LDL and/or $\beta$-GP. Ox-LDL alone slightly increased cbfa- 1 , but the increase was not significant compared with the control. Ox-LDL plus $\beta$-GP increased the expression of cbfa- 1 by 2.2 -fold relative to the control. The expression of OPG decreased by approximately 50\%-60\% in groups treated with ox-LDL (Figure 3A). OCN expression did not change in any of the groups after $7 \mathrm{~d}$ of induction. We extended the time of treatment to $10 \mathrm{~d}$ and the level of OCN increased approximately 1.6-fold in both ox-LDL and $\beta$-GP groups; moreover, there was a 2.8 -fold increase in oxLDL plus $\beta$-GP group relative to the control (Figure $3 \mathrm{~B}$ ). The results showed that the expression of certain bone-associated genes in BMEPCs could be changed by treatment with ox-LDL and $\beta$-GP. Furthermore, ox-LDL had a synergistic effect with $\beta$-GP.

\section{Increased ALP activity in BMEPCs}

ALP activity was determined after ox-LDL/ $\beta$-GP incubation for $11 \mathrm{~d}$ by a colorimetric assay. Control cells showed low ALP activity, but treatment with ox-LDL increased ALP activity 1.2 -fold, which was similar to $\beta$-GP treatment. There was a 1.5-fold increase in cells treated with both ox-LDL and $\beta$-GP (Figure 4). ALP is a representative marker of bone formation; therefore, the data suggest that BMEPCs responded to the increased activity of bone-associated proteins.

\section{No difference of $\mathrm{OCN}^{+}$BMEPCs}

Immunofluorescence detection of OCN was performed after

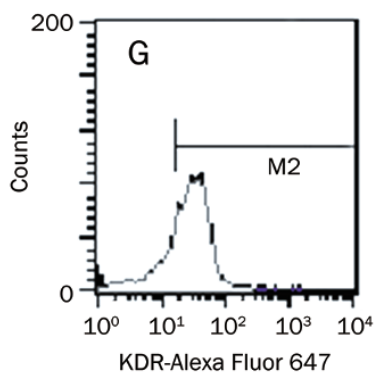

(100×); (B) Adherent cells with green FITC-UEA-1; (C) Adherent cells with red Dil-ac-LDL; (D) Dual-positive cells with orange were identified as differentiating BMEPCs (200×); (E, F, G) The M2 gate in histograms from flow cytometer showed the percentages of CD34, CD133 and KDR stained with fluoresceins-labeled antibodies. Results were displayed as mean \pm SD $(n=4)$.
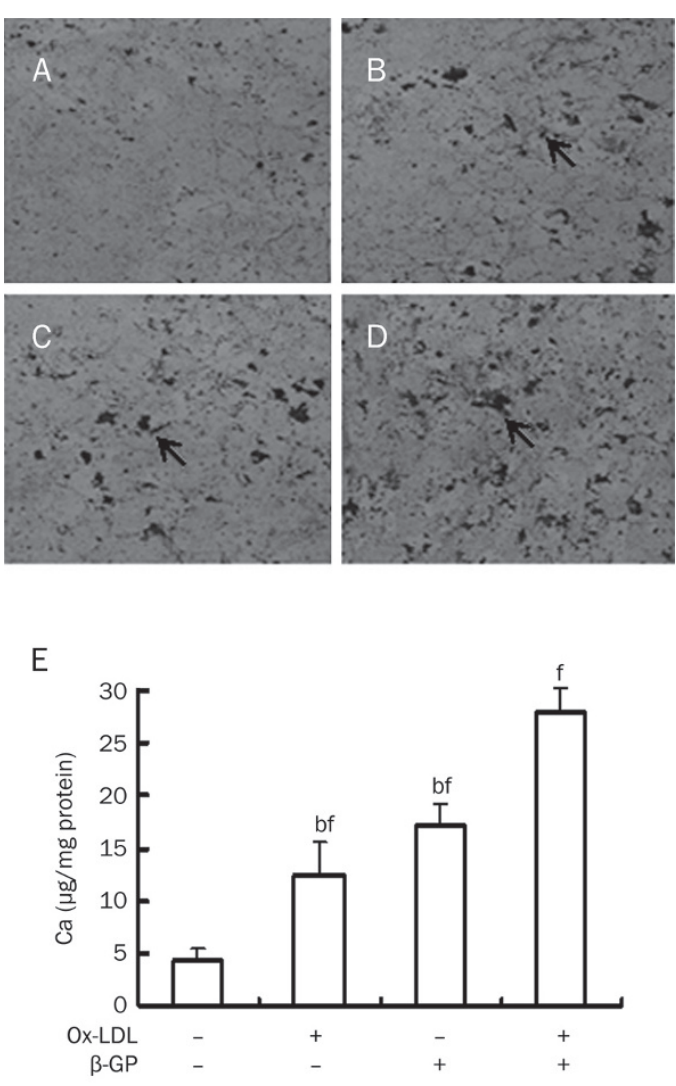

Figure 2. Calcium deposition of BMEPCs. BMEPCs were incubated for $14 \mathrm{~d}$ with $5 \mu \mathrm{g} / \mathrm{mL}$ ox-LDL and/or $10 \mathrm{mmol} / \mathrm{L} \beta$-GP. The effects of ox-LDL on calcification were assessed by the content of calcium and Von Kossa staining. Calcium nodule displayed black or deep-brown granules and local cord-like shapes ( $\times 40$, pointed out with arrows). (A) Control; (B) OxLDL; (C) $\beta$-GP; (D) Ox-LDL plus $\beta$-GP. Results were displayed as mean $\pm S D$ $(n=3)$. ${ }^{b} P<0.05$ vs ox-LDL plus $\beta$-GP group. ${ }^{f} P<0.01$ vs control. 

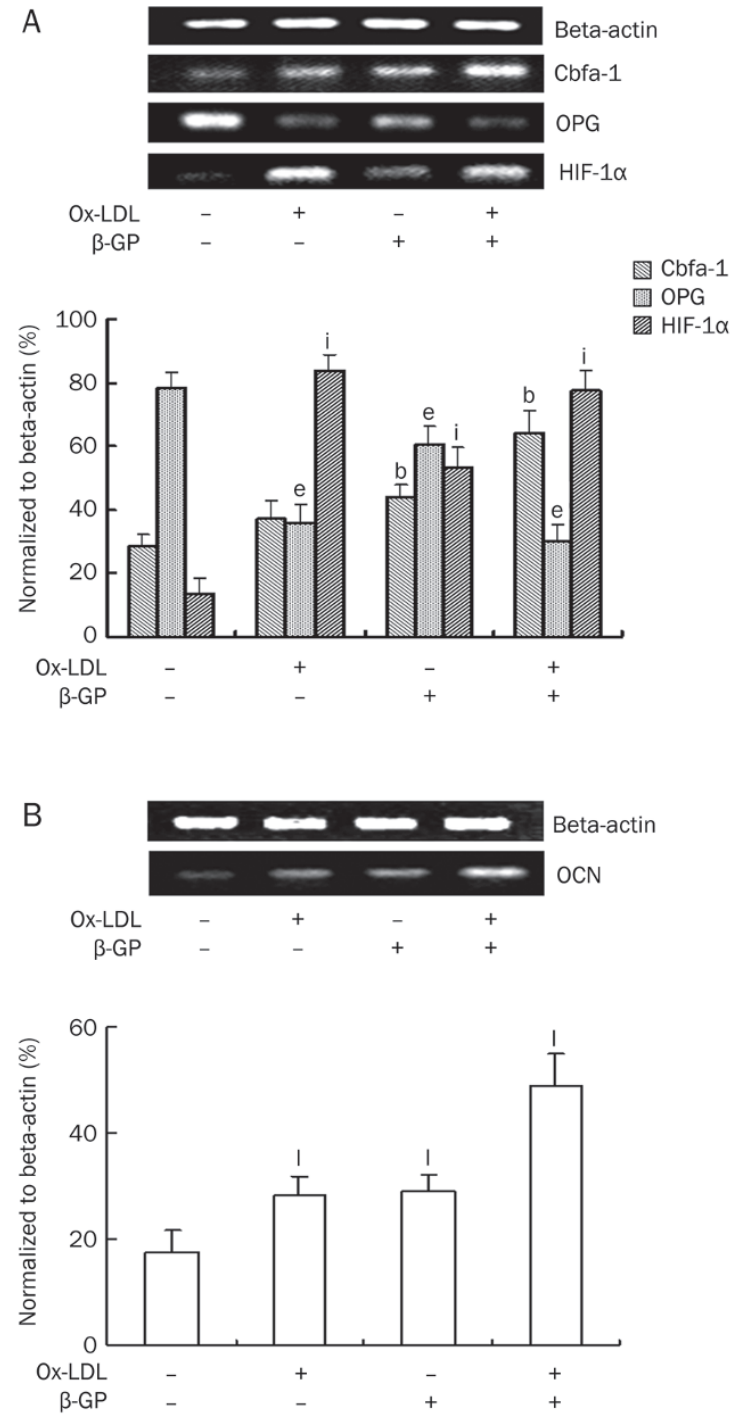

Figure 3. Expression of osteogenic genes. BMEPCs were incubated with $5 \mu \mathrm{g} / \mathrm{mL}$ ox-LDL and/or $10 \mathrm{mmol} / \mathrm{L} \beta$-GP. The levels of osteogenic genes were assessed by RT-PCR. The ratios were normalized to beta-actin. (A) Genes of $7 \mathrm{~d}$; (B) Genes of $10 \mathrm{~d}$. Results were displayed as mean $\pm S D$ $(n=3-5) .{ }^{b} P<0.05$ vs cbfa- 1 of control. ${ }^{\mathrm{e}} P<0.05$ vs OPG of control. i $P<0.01$ vs HIF- $1 \alpha$ of control. ' $P<0.01$ vs $\mathrm{OCN}$ of control.

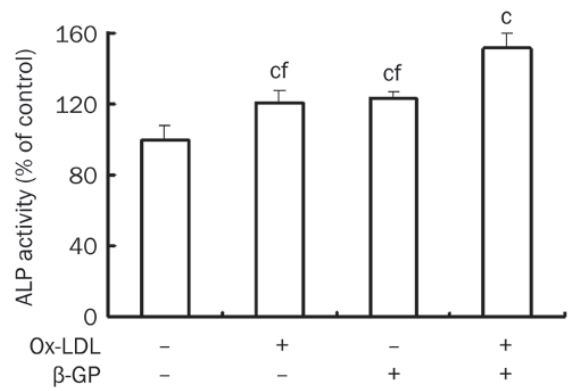

Figure 4. ALP activity. BMEPCs were incubated for $11 \mathrm{~d}$ with $5 \mu \mathrm{g} / \mathrm{mL}$ ox-LDL and $10 \mathrm{mmol} / \mathrm{L} \beta$-GP. ALP activity was determined by colorimetric. Results were displayed as mean $\pm \operatorname{SD}(n=3)$. The activity displayed as the percentage of control. ${ }^{c} P<0.01$ vs control. ${ }^{f} P<0.01$ vs ox-LDL plus $\beta$-GP group.
$14 \mathrm{~d}$ of treatment with ox-LDL and $\beta$-GP. $\mathrm{OCN}^{+}$cells were counted under the microscope in ten random visual fields at a magnification of $200 \times$. The immunopositive cells were easily identified (Figure 5), but there was no difference among the groups.

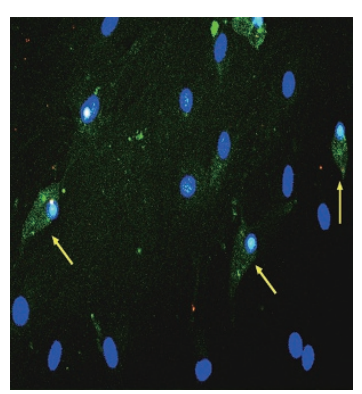

Figure 5. Immunofluorescence for OCN. BMEPCs were incubated for 14 $\mathrm{d}$ with $5 \mathrm{\mu g} / \mathrm{mL}$ ox-LDL and/or $10 \mathrm{mmol} / \mathrm{L} \beta$-GP. Monoclonal antibody and FITC labeled second antibody were used. The positive cells (pointed out with arrows) showed fusiform-like appearance. $\times 200$.

\section{Contribution of oxidative stress to ossification}

To assess the mechanism of ossification induced by ox-LDL, intracellular ROS was determined. Fluorescence intensity data are shown as a percentage of the control. During the inducible process, ROS increased persistently, yet it improved at $5 \mathrm{~d}$ than at $1 \mathrm{~d}$. In the ox-LDL-treated group, ROS increased 3.8fold, 2.7-fold and 2.4-fold at $1 \mathrm{~d}, 3 \mathrm{~d}$, and $5 \mathrm{~d}$, respectively. A similar change occurred in the ox-LDL plus $\beta$-GP group. The results showed that the early phase of transdifferentiation induced by ox-LDL was accompanied by high levels of ROS. After $3 \mathrm{~d}$, a relatively stable level of ROS was maintained (Figure 6). Moreover, HIF-1a, which acts as a regulatory factor for differentiation under hypoxia, also increased more than 5-fold in the ox-LDL treated groups after treatment for $7 \mathrm{~d}$ (Figure 3A). We also assessed HIF-1a at $1 \mathrm{~d}$ and $3 \mathrm{~d}$, but no apparent expression was detected. The results indicate that

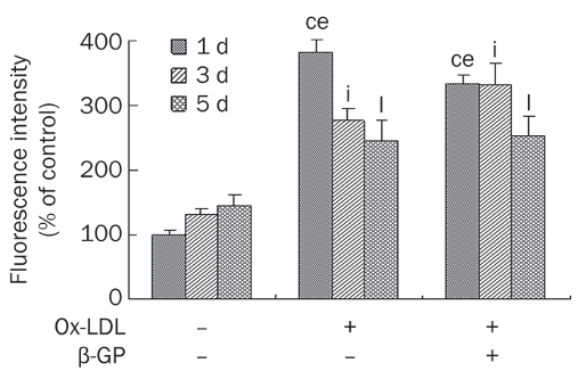

Figure 6. Effects of ox-LDL on ROS production in BMEPCs. BMEPCs were treated for $1 \mathrm{~d}, 3 \mathrm{~d}$, and $5 \mathrm{~d}$ with $5 \mu \mathrm{g} / \mathrm{mL}$ ox-LDL and/or $10 \mathrm{mmol} / \mathrm{L} \beta$-GP and were stained with DCHF-DA. Flow cytometric analysis was performed to determine the mean fluorescence intensity of DCF-positive cells. Data were shown as the percentage of control. Results were displayed as mean \pm SD $(n=3) .{ }^{c} P<0.01$ vs control at $1 \mathrm{~d}$. ${ }^{e} P<0.05$ vs the same group at $5 \mathrm{~d}$. ${ }^{i} P<0.01,{ }^{\prime} P<0.01$ vs control at $3 \mathrm{~d}$ and $5 \mathrm{~d}$, respectively. 
ROS and HIF-1a were activated successively during the ossification process.

\section{Discussion}

EPCs can be isolated from peripheral blood, spleen, bone marrow and adipose tissue. They express cell markers of both stem cells and endothelial cells. Because of different culture conditions, the percentage of cell markers identified was neither exact nor unified. In our study, the medium, which was supplied with a high concentration of VEGF and bFGF, could be used to selectively culture EPCs with spindle morphology and the phagotrophic function of the endothelium. In combination with a special set of cell markers (CD34, CD133, KDR), the cells isolated from bone marrow were mostly identified as a mixture of EPCs and immature endothelial cells. Because endothelial cells do not differentiate, the ossific effects identified in our study came from BMEPCs. Thus, this method could provide another stem cell model for vascular ossification in addition to monocytic progenitor cells and MSCs ${ }^{[14,15]}$.

Ox-LDL contributes to vascular calcification by inducing smooth muscle cells and foam cells to initiate fibrosis and form atheromas, which is followed by an increase in calcium deposition ${ }^{[16]}$. There is a positive correlation between coronary calcium or instability of coronary plaques and plasma ox-LDL level ${ }^{[17]}$. In vitro ox-LDL increased ALP activity, induced transient and strong expression of bone morphogenetic protein 2 (BMP2) and matrix gla-protein (MGP) and accelerated mineralization ${ }^{[18]}$. However, ox-LDL treatment at specified concentrations inhibited Pi-induced UMR106 rat osteoblast mineralization and bone associated proteins, suggesting that ox-LDL would simply be a risk factor for the presence of atherosclerosis, rather than pathological in atherosclerosis complications ${ }^{[19]}$. Therefore, the effect of ox-LDL on vascular calcification is controversial ${ }^{[20]}$. In our study, ox-LDL and/or $\beta$-GP increased calcium deposition and ALP activity. The results were consistent with other reports ${ }^{[21]}$. Genes promoting calcification (cbfa-1, $\mathrm{OCN}$ ) increased and genes inhibiting calcification (OPG) decreased, indicating the ossific process induced by ox-LDL was dual-regulatory. However, the effect on changes in bone gene expression was not strong. One potential explanation is that the culture conditions might require a more complicated microenvironment such as the addition of calcium ions. It was reported that $\mathrm{CD} 34^{+}$cells, pretreated with $5 \mathrm{mmol} / \mathrm{L} \mathrm{Ca}^{2+}$, had more changes in bone gene expression than those without $\mathrm{Ca}^{2+[4]}$. In addition, ox-LDL had no apparent effect on increasing the number of $\mathrm{OCN}^{+}$cells. There were several possible reasons as for these findings. The complicated process from gene transcription to protein expression may require more regulatory elements. Furthermore, the OCN protein was present in low abundance in BMPECs, meaning that identification of the different concentrations of $\mathrm{OCN}$ in the treated groups was challenging.

Vascular calcification and oxidative stress occur in parallel. Low concentrations of $\mathrm{H}_{2} \mathrm{O}_{2}$ increase ALP activity and potentiate the progression of aortic valve calcification ${ }^{[22,23]}$. The levels of expression of mRNAs for OPN and OCN were significantly greater in ROS-treated human dental pulp cells ${ }^{[24]}$. Thus, rather than simply causing oxidative damage, ROS played a more complex role in cell physiology. HIF-1a is a transcription factor that regulates stem cell differentiation during hypoxia ${ }^{[25]}$. Overexpression of HIF-1a in mature osteoblasts profoundly increases angiogenesis and osteogenesis ${ }^{[26]}$. Both of these processes are activated concomitantly to promote intra-plaque angiogenesis and foam cell development ${ }^{[27]}$. Our results displayed higher levels of early-phase ROS generation followed by a significant increase in the expression of HIF-1a. Thus, it could be speculated that ox-LDL induces ossification of BMEPCs through ROS mediation of an increase in HIF-1a nucleotide level.

The effect of ox-LDL on cell differentiation has been fully explained to different degrees ${ }^{[11,28]}$. Our study presents, for the first time, the effects of ox-LDL on transdifferentiation of BMEPCs. BMEPCs might be considered a new member involved in vascular calcification; however, because ox-LDLinduced vascular calcification is a complex process, the cell system in vitro is perhaps too simple to represent the actual microenvironment in vivo. Oxidative stress alone cannot explain the mechanism clearly, which means that there must be other signaling pathways that participate in the process.

In conclusion, we have shown that BMEPCs can be induced to ossific differentiation. Ox-LDL acts synergistically with $\beta$-GP and contributes to calcification to some extent, with an oxidative stress mechanism underlying the phenomenon. Our results offer another target for vascular calcification therapy.

\section{Acknowledgements}

This work was supported by the National Basic Research Program of China (973 Program, № 2007CB512503).

\section{Author contribution}

Li LIU and Xi-xiong KANG designed the research; Li LIU, Hui CHEN, and Yu-hua KONG performed the research; Li LIU and Zhi-zhong LIU analyzed the data; and Li LIU and Guojun ZHANG wrote the manuscript.

\section{References}

1 Tyson KL, Reynolds JL, McNair R, Zhang Q, Weissberg PL, Shanahan CM. Osteo/chondrocytic transcription factors and their target genes exhibit distinct patterns of expression in human arterial calcification. Arterioscler Thromb Vasc Biol 2003; 23: 489-94.

2 Tousoulis D, Andreou I, Antoniades C, Tentolouris C, Stefanadis C. Role of inflammation and oxidative stress in endothelial progenitor cells function and mobilization: Therapeutic implications for cardiovascular diseases. Atherosclerosis 2008; 201: 236-47.

3 lyemere VP, Proudfoot D, Weissberg PL, Shanahan CM. Vascular smooth muscle cell phenotypic plasticity and the regulation of vascular calcification. J Intern Med 2006; 260: 192-210.

4 Gossi M, Modder UI, Atkinson EJ, Lerman A, Khosla S. Osteocalcin expression by circulating endothelial progenitor cells in patients with coronary atherosclerosis. J Am Coll Cardiol 2008; 52: 1314-25.

5 Moeddera UI, Gosslb M, Lerma LO, Khosla S, Lerman A. Circulating endothelial progenitor cells co-expressing an osteogenic phenotype are increased in patients with severe calcific aortic valve stenosis. 
Bone 2009; 44: S321.

6 Sata M, Fukuda D, Tanaka K, Kaneda Y, Yashiro H, Shirakawa I. The role of circulating precursors in vascular repair and lesion formation. J Cell Mol Med 2005; 9: 557-68.

7 Côté C, Pibarot P, Després JP, Mohty D, Cartier A, Arsenault BJ, et al. Association between circulating oxidized low-density lipoprotein and fibrocalcific remodelling of the aortic valve in aortic stenosis. Heart 2008; 94: 1175-80.

8 Wu Y, Wang Q, Cheng L, Wang J, Lu G. Effect of oxidized low-density lipoprotein on survival and function of endothelial progenitor cell mediated by p38 signal pathway. J Cardiovasc Pharmacol 2009; 53: 151-6.

9 Imanishi T, Hano T, Sawamura T, Nishio I. Oxidized low-density lipoprotein induces endothelial progenitor cell senescence, leading to cellular dysfunction. Clin Exp Pharmacol Physiol 2004; 31: 407-13.

10 Imanishi T, Hano T, Matsuo Y, Nishio I. Oxidized low-density lipoprotein inhibits vascular endothelial growth factor-induced endothelial progenitor cell differentiation. Clin Exp Pharmacol Physiol 2003; 30: 665-70.

11 Taylor J, Butcher M, Zeadin M, Politano A, Shaughnessy SG. Oxidized low-density lipoprotein promotes osteoblast differentiation in primary cultures of vascular smooth muscle cells by up-regulating Osterix expression in an Msx2-dependent manner. J Cell Biochem 2011; 112: 581-8.

12 Sun CK, Lee FY, Sheu JJ, Yuen CM, Chua S, Chung SY, et al. Early combined treatment with cilostazol and bone marrow-derived endothelial progenitor cells markedly attenuates pulmonary arterial hypertension in rats. J Pharmacol Exp Ther 2009; 330: 718-26.

13 Van Campenhout A, Moran CS, Parr A, Clancy P, Rush C, Jakubowski H, et al. Role of homocysteine in aortic calcification and osteogenic cell differentiation. Atherosclerosis 2009; 202: 557-66.

14 Kuwana M, Okazaki Y, Kodama H, Izumi K, Yasuoka H, Ogawa Y, et al. Human circulating $\mathrm{CD} 14^{+}$monocytes as a source of progenitors that exhibit mesenchymal cell differentiation. J Leukoc Biol 2003; 74: 833-45.

15 Zvaifler NJ, Marinova-Mutafchieva L, Adams G, Edwards CJ, Moss J, Burger JA, et al. Mesenchymal precursor cells in the blood of normal individuals. Arthritis Res 2000; 2: 477-88.

16 Mody N, Parhami F, Sarafian TA, Demer LL. Oxidative stress modulates osteoblastic differentiation of vascular and bone cell. Free Radic Biol Med 2001; 31: 509-19.

17 Ehara S, Naruko T, Shirai N, Itoh A, Hai E, Sugama Y, et al. Small coronary calcium deposits and elevated plasma levels of oxidized low density lipoprotein are characteristic of acute myocardial infarction. J Atheroscler Thromb 2008; 15: 75-81.

18 Cola C, Almeida M, Li D, Romeo F, Mehta JL. Regulatory role of endothelium in the expression of genes affecting arterial calcification. Biochem Biophys Res Commun 2004; 320: 424-7.

19 Mazière C, Savitsky V, Galmiche A, Gomila C, Massy Z, Mazière JC. Oxidized low density lipoprotein inhibits phosphate signaling and phosphate-induced mineralization in osteoblasts. Involvement of oxidative stress. Biochim Biophys Acta 2010; 1802: 1013-9.

20 Johnson RC, Leopold JA, Loscalzo J. Vascular calcification: pathobiological mechanisms and clinical implications. Circ Res 2006; 99: 1044-59.

21 Bear M, Butcher M, Shaughnessy SG. Oxidized low-density lipoprotein acts synergistically with beta-glycerophosphate to induce osteoblast differentiation in primary cultures of vascular smooth muscle cells. J Cell Biochem 2008; 105: 185-93.

22 Liberman M, Bassi E, Martinatti MK, Lario FC, Wosniak J Jr, Pomerantzeff PM, et al. Oxidant generation predominates around calcifying foci and enhances progression of aortic valve calcification. Arterioscler Thromb Vasc Biol 2008; 28: 463-70.

23 Lee DH, Lim BS, Lee YK, Yang HC. Effects of hydrogen peroxide $\left(\mathrm{H}_{2} \mathrm{O}_{2}\right)$ on alkaline phosphatase activity and matrix mineralization of odontoblast and osteoblast cell lines. Cell Biol Toxicol 2006; 22: 39-46.

24 Matsui S, Takahashi C, Tsujimoto Y, Matsushima K. Stimulatory effects of low-concentration reactive oxygen species on calcification ability of human dental pulp cells. J Endod 2009; 35: 67-72.

25 Francis KR, Wei L. Human embryonic stem cell neural differentiation and enhanced cell survival promoted by hypoxic preconditioning. Cell Death Dis 2010; 1: e22.

26 Wan C, Shao J, Gilbert SR, Riddle RC, Long F, Johnson RS, et al. Role of HIF-1alpha in skeletal development. Ann N Y Acad Sci 2010; 1192: 322-6.

27 Shatrov VA, Sumbayev VV, Zhou J, Brune B. Oxidized low-density lipoprotein (oxLDL) triggers hypoxia-inducible factor-1 $\alpha$ (HIF-1 $\alpha$ ) accumulation via redox-dependent mechanisms. Blood 2003; 101: 4847-9.

28 Lu T, Parthasarathy S, Hao H, Luo M, Ahmed S, Zhu J, et al. Reactive oxygen species mediate oxidized low-density lipoprotein-induced inhibition of oct-4 expression and endothelial differentiation of bone marrow stem cells. Antioxid Redox Signal 2010; 13: 1845-56. 